\title{
PENYEDIAAN DATABASE HUKUM NASIONAL MENDUKUNG REFORMASI HUKUM JILID II: PERAN JDIHN
}

\author{
Oleh: Theodrik Simorangkir ${ }^{*}$ \\ Pusat Dokumentasi dan Jaringan Informasi Huum Nasional \\ Jalan Mayjen. Sutoyo No. 10 Cililitan Jakarta Timur Indonesia \\ Email: theodriksimorangkir@gmail.com
}

\begin{abstract}
ABSTRAK
Pembangunan hukum nasional melalui Agenda Reformasi Hukum Jilid II membutuhkan akses informasi hukum yang efektif. Dalam hal ini, penyediaaan Database Hukum Nasional dengan konten informasi hukum terintegrasi menjadi penting, karena dengan tersedianya database ini maka semua bahan baku pembangunan hukum dapat diakses atau disediakan dengan mudah, cepat, tepat, dan komprehensif. Teknologi Informasi dan komunikasi (TIK) yang tersedia saat ini sangat memungkinkan penyediaan database tersebut. Penyediaan database ini merupakan tugas dokumentasi hukum Pusat dan Anggota Jaringan Dokumentasi dan Informasi Hukum Nasional (JDIHN). Namun dalam kenyataannya Pusat dan Anggota JDIHN masih perlu dikuatkan. Artikel ini mengidentifikasi masalah yang dihadapi oleh Pusat dan Anggota JDIHN dalam penyediaan Database Hukum Nasional. Masalah dijawab menggunakan metode penelitian kepustakaan dengan analisis deskriptifkualitatif dan pendekatan fungsi-fungsi dokumentasi. Hasil penelitian menunjukkan bahwa masalah yang dihadapi masih sangat mendasar meliputi konsep dan teknis dokumentasi serta bagaimana memanfaatkan TIK. Kemudian merekomendasikan agar semua pokokpokok pikiran hasil penelitian disosialisasikan kepada semua anggota JDIHN melalui berbagai kegiatan pembinaan dan pengembangan.
\end{abstract}

Kata kunci: pembangunan hukum, dokumentasi hukum, database hukum, akses informasi hukum, jaringan dokumentasi dan informasi hukum.

\begin{abstract}
Development of national law through Law Reform Agenda Volume II requires effective access to law information. In this case, the provision of the National Law Database with integrated legal information content being important, because of the availability of this database then all law development raw materials can be accessed or prepared easily, quickly, precisely, and comprehensively. Information and communication technology (ICT) currently available is very possible to provide the database. The provision of this database is the task of law documentation Center and Member of the National Law Documentation and Information Network (JDIHN). But in reality the center and members JDIHN still needs to be strengthened. This article identifies problems faced by the Center and Member of JDIHN in the provision of the National Law Database. Problems are answered using the method of literature research with qualitative descriptive analysis and documentation functions approach. The results of the study show that the problems faced are still very basic includes concepts and technical documentation as well as how to utilize ICT. Then recommends that all the basic thoughts of the research results be socialized to all JDIHN members through various development and strengthening activities.
\end{abstract}

*) Ahli Pustakawan Utama. Koordinator Pustakawan di Pusat Jaringan Dokumentasi dan Informasi Hukum Nasional. 
Keywords: law development, law documentation, law database, law information access, documentation and information law network

A. Pendahuluan

Berbicara tentang Jaringan Dokumentasi dan Informasi Hukum Nasional (JDIHN), tidak mungkin terlepas dari pembangunan hukum nasional, karena tujuan utama dari pembentukan JDIHN adalah untuk mendukung percepatan pembangunan hukum nasional. Ide membentuk JDIHN muncul dalam Seminar Hukum Nasional ke III pada tahun 1974 di Surabaya. Dalam seminar tersebut diketahui bahwa salah satu masalah yang mengakibatkan pembangunan hukum tidak dapat berjalan sebagaimana yang diharapkan adalah lemahnya dukungan dokumentasi hukum. Jelasnya, dokumentasi hukum belum mampu menyediakan bahan baku ${ }^{1}$ pembangunan hukum berupa dokumendokumen hukum dengan cepat, tepat, dan komprehensif. Faktor penyebab lemahnya dukungan dokumentasi hukum terhadap pembangunan hukum nasional antara lain:

"1.Dokumen hukum potensial, tersebar luas di instansi pemerintah di pusat sampai daerah dengan wilayah kepulauan yang sangat luas;

2. Dokumen-dokumen hukum tersebut belum semuanya dikelola dengan baik dalam suatu sistem;

3. Tenaga pengelola yang ada sangat kurang;
4. Perhatian terhadap keberadaan dokumentasi dan perpustakaan hukum masih sangat kurang." 2

Melihat kompleksitas masalah dokumentasi hukum yang sedemikian besar pengaruhnya terhadap pelaksanaan pembangunan hukum, peserta seminar sepakat merekomendasikan kepada pemerintah:

"1.Perlu adanya suatu kebijakan nasional untuk menyusun sistem jaringan dokumentasi dan informasi hukum dan agar segera dapat berfungsi.

2. Dalam tahap permulaan, perlu dilakukan dua hal:

a. Untuk mempermudah pencarian dan penemuan kembali informasi dan dokumen hukum perlu dilakukan perbaikan cara pengundangan dan penerbitan peraturan perundang-undangan. Serta membuat sarana temu kembali (katalog) dan diterbitkan secara teratur;

b. Untuk dapat secepatnya mendayagunakan semua informasi yang ada Jaringan Dokumentasi dan Informasi Hukum (JDI-Hukum) perlu disusun dan dikembangkan. Ditentukan Pusat dan Anggota Jaringan serta sediakan sarana yang diperlukan agar mulai berfungsi dalam Pelita II." ${ }^{3}$
1 M. Budiarto (Ses. BPHN). Peranan Dokumentasi dan Informasi Hukum Dalam Rangka Menunjang Para Pejabat Pengambil Keputusan. Makalah disampaikan dalam Pengarahan Pada Latihan Tenaga Teknis Dokumentasi ddan Informasi Hukum Tingkat Dasar Departemen Kehakiman, 11 Peburari 1991 s.d. 12 Maret 1991 di Jakarta.
Himpunan Hasil Seminar Hukum Nasional I-VII dan Seminar Akbar 50 Tahun Pembinaan Hukum. Jakarta: PNRI, 2003, hlm. 64.

3 Ibid, lihat juga Harjito Notopuro. Tugas dan Peranan Pusat Dokumentasi Hukum Badan Pembinaan Hukum Nasional dalam rangka pengembangan sistem jaringan dokumentasi dan informasi hukum. Jakarta, BPHN, 1980, hlm. 7. 
Rekomendasi Seminar Hukum tersebut di atas direspon oleh pemerintah pada era permulaan reformasi dengan mengundangkan Keputusan Presiden Nomor 91 Tahun 1999 tentang Jaringan Dokumentasi dan Informasi Hukum Nasional dalam Lembaran Negara No. 135. Kemudian dalam rangka melaksanakan Rencana Aksi Presiden dalam pencegahan dan pemberantasan korupsi ${ }^{4} \quad$ Keputusan Presiden tersebut direvitalisasi dan diganti dengan Peraturan Pemerintah Nomor 33 Tahun 2012 tentang Jaringan Dokumentasi dan Informasi Hukum Nasional, Lembaran Negara No 82.

Sebagai kebijakan pemerintah, Peraturan Presiden Nomor 33 Tahun 2012 mengatur kerja sama pengelolaan dokumen dan informasi hukum. Berdasarkan kebijakan presiden ini diharapkan semua permasalahan dokumentasi hukum yang ada dapat diselesaikan dengan baik, dan dengan demikian kerja sama pengelolaan dokumen dan informasi hukum mampu menyediakan akses informasi hukum yang efektif mendukung pembanguan hukum nasional dengan agenda Reformasi Hukum Jilid II. Dalam era TIK (teknologi informasi dan komunikasi) media akses informasi hukum yang paling efektif adalah tersedianya Database Hukum Nasional yang kontennya informasi hukum terintegrasi. Penyediaan Database Hukum Nasional ini merupakan tugas pokok dari dokumentasi hukum Pusat dan Anggota JDIHN.

$$
\text { Melalui pengamatan dan }
$$
pengalaman sebagai pengelola dokumen dan informasi hukum, ternyata sampai saat ini, faktor-faktor yang menyebabkan lemahnya dokumentasi hukum di atas

Indonesia. Instruksi Presiden Nomor 9 Tahun 2011 tentang Rencana Aksi Pencegahan dan Pemerantasan Korupsi Tahun 2011. Lampiran point 72. masih eksis. Berkaitan dengan hal ini, Kepala Pusat JDIHN tahun 2011 mengatakan:

"Jika diamati secara cermat, akar permasalahannya terletak pada lemahnya pemahaman tentang tugas pokok dan fungsi dokumentasi hukum. Hal ini mengakibatkan perhatian terhadap penyediaan sumber daya dokumentasi sering luput dari perhatian. Kalaupun mendapat perhatian, hanya secara partial belum sistemik." ${ }^{5}$

Selain itu akibat kurangnya perhatian terhadap dokumentasi, di benak berbagai kalangan, dokumentasi masih dicitrakan sebagai pekerjaan sepele (mudah) yang dapat dilakukan oleh siapa saja, tidak perlu dikerjakan secara profesional. Akibatnya informasi dan dokumen hukum masih sulit dicari (searching) dan ditemukan kembali (retrieval). Bahkan untuk menentukan berapa jumlah peraturan, berapa jumlah hasil penelitian hukum, masih sulit diberikan jawaban yang pasti.

Dalam kondisi seperti ini disinyalir peraturan perundang-undangan mengandung banyak permasalahanpermasalahan regulasi, antara lain: 1) Terlalu banyak regulasi (hyperregulation); 2) Saling bertentangan; 3) Tumpang tindih (Overlapping); 4) Multitafsir; 5) Tidak taat asas (inconsistency); 6) Tidak efektif; 7) Menciptakan beban yang tidak perlu; dan 8) Menciptakan Ekonomi Biaya Tinggi (Hight Cost Eonomy). ${ }^{6}$

5 Wicipto Setiadi. kebijakan badan pembinaan hukum nasional dalam pembinaan dan pengembangan Jaringan Dokumentasi Dan Informasi Hukum Nasional. Makalah disampaikan dalam Pertemuan Berkala Ke XX Anggota JDIHukum Nasional Wilayah Barat tanggal 24 s.d. 26 Mei 2011 di Palembang, hlm. 6.

6 Keynote Speech Menteri Hukum dan HAM RI disampaikan dalam Rapat Koordinasi Penataan 
Mengatasi berbagai permasalahan regulasi di atas, Presiden Jokowi mengatakan penataan regulasi harus menjadi prioritas reformasi hukum. ${ }^{7}$ Reformasi Hukum Jilid II mencanangkan Agenda Penataan Regulasi mencakup 3 (tiga) hal, yaitu: 1) Penguatan pembentukan peraturan perundangundangan; 2) Evaluasi seluruh peraturan perundang-undangan; 3) Pembuatan database peraturan perundangundangan. ${ }^{8}$

Agenda penataan regulasi ini merupakan tugas besar dan tanggung jawab dari semua Kementerian, Lembaga Non Kementerian dan Pemerintah Daerah. Untuk mempercepat penyelesaiannya, semua pihak terkait harus terlibat dan bekerja dengan serius. Menurut Menteri Hukum dan HAM, para pihak terkait harus mengupayakan agar penataan regulasi didukung dengan dokumen hukum yang lengkap. ${ }^{9}$ Selanjutnya menjelaskan bahwa dokumen hukum yang dimaksud tidak hanya peraturan perundang-undangan termasuk juga putusan pengadilan, yurisprudensi, monografi hukum, artikel hukum, hasil penelitian, naskah akademik, dan rancangan peraturan perundang-undangan beserta memory van toelichting-nya.$^{10}$

Pernyataan-pernyataan di sekitar masalah regulasi di atas patut diduga ada kaitannya dengan kinerja dokumentasi hukum yang belum mampu menyediakan data dukung (dokumen hukum) pembangunan hukum yang lengkap untuk pembentukan peraturan perundang-undangan. Akibatnya muncul regulasi yang tumpang tindih, peraturan

Regulasi diselenggarakan oleh BPHN. Jakarta, 7 Februari 2018, hlm. 2.

Ibid.

Ibid., hlm. 3.

Ibid., hlm. 4 dan 5.

Ibid., hlm. 6. yang multitafsir, tidak taat asas dan tidak efektif. Memang tidak dapat dipungkiri bahwa pencarian (searching) informasi dan temu kembali (retrieval) dokumen hukum masih sulit dilakukan sampai saat ini karena akses informasi hukum belum tersedia dengan baik.

Lembaga yang bertanggung jawab menyediakan akses informasi hukum di instansi pemerintah maupun instansi lain adalah dokumentasi hukum. Pada umumnya di instansi pemerintah, dokumentasi hukum berada Biro Hukum dan Bagian Hukum. Dalam Peraturan Presiden Nomor 33 Tahun 2013 tentang Jaringan Dokumentasi dan Informasi Hukum Nasional (Perpres 33/2013 tentang JDIHN) instansi tersebut telah ditetapkan sebagai Anggota JDIHN. ${ }^{11}$ Dokumentasi hukum Anggota JDIHN inilah yang bertugas menyediakan dokumen hukum (data dukung) untuk semua aktivitas reformasi pembangunan hukum, khususnya reformasi hukum Jilid II.

Dalam era TIK (Teknologi Informasi dan Komunikasi) dewasa ini tata kelola dokumen hukum berbasis database website sudah menjadi suatu keharusan. Pemanfaatan TIK dalam tata kelola dokumentasi, di samping mampu

11 Indonesia. Peraturan Presiden Nomor 33 Tahun 2012 Pasal 4 (3): Anggota JDIHN ... terdiri atas:

a. Biro Hukum dan/atau unit kerja yang tugas dan fungsinya menyelenggarakan kegiatan yang berkaitan dengan dokumen hukum pada:

1. Kementerian Negara;

2. Sekretariat Lembaga Negara;

3. Lembaga Pemerintah Non Kementerian;

4. Pemerintah Provinsi;

5. Pemerintah Kabupaten/Kota; dan

6. Sekretariat Dewan Perwakilan Rakyat Daerah Tingkat Provinsi dan Kabupaten/Kota;

b. Perpustakaan pada perguruan tinggi negeri dan perguruan tinggi swasta;

c. Lembaga Lain yang bergerak di bidang pengembangan dokumentasi dan informasi hukum yang ditetapkan oleh Menteri. 
meningkatkan kinerja, juga mampu membentuk database hukum nasional dengan content informasi hukum terintegrasi. Bermuara pada tersedianya akses informasi hukum terintegrasi yang memudahkan pencarian informasi dan dokumen hukum dengan cepat, tepat dan komprehensip.

Dengan tersedianya akses informasi hukum terintegrasi dalam satu database hukum nasional, maka penataan regulasi dapat dilakukan dengan cepat dan berkualitas, karena pencarian (searching) informasi dan temu kembali (retrieval) dokumen hukum dapat dilakukan dengan secepat-cepatnya, setepat-tepatnya dan selengkap-lengkapnya (comprehensive).

Dalam rangka menyamakan persepsi dan sekaligus memahami peran JDIHN dalam penyediaan database hukum nasional untuk mendukung pembangunan hukum nasional termasuk Reformasi Hukum Jilid II, makalah ini menjelaskan beberapa hal penting yang perlu mendapat perhatian serius, antara lain:

1. Apa hubungan dokumentasi hukum dengan pembangunan hukum?

2. Apa dokumentasi hukum, tupoksi dan sumber dayanya?

3. Mengapa JDIHN dibentuk?

4. Apa objek kerja sama JDIHN?

5. Bagaimana bentuk dan prinsip kerja sama JDIHN?

6. Apa yang dimaksud dengan informasi hukum terintegrasi?

7. Bagaimana cara memanfaatkan TIK dalam pembentukan database hukum nasional?

\section{B. Metode Penelitian}

Pendekatan yang digunakan untuk mengkaji dan menganalisis permasalahan dalam tulisan ini menggunakan pendekatan fungsi dokumentasi hukum dalam konteks pembangunan hukum nasional. Pendekatan ini digunakan karena dokumentasi hukum merupakan salah satu unsur pembangunan hukum nasional yang sangat strategis namun sering terlupakan. Dokumentasi hukum sebagai suatu unsur pembangunan hukum ditugasi menyediakan bahan baku atau data dukung dengan cepat, tepat, dan lengkap. Sebagai suatu kegiatan dokumentasi hukum bertujuan menyedia-kan akses informasi hukum yang efektif. Oleh karena itu metode penelitian yang digunakan merupakan penelitian literatur dengan meneliti bahan primer, sekunder maupun bahan tertier. Argumentasi dan hasil analisis dilakukan secara kualitatif berdasarkan fungsi-fungsi dan teknik dokumentasi hukum dan kesimpulan ditarik dari argumentasi dan hasil hasil analisis.

\section{Pembahasan}

1. Dokumentasi Hukum dan Pembangunan Hukum

Dalam sistem pembangunan hukum nasional, dokumentasi hukum merupakan salah satu sub-sistem yang penting dan tidak terpisahkan dalam kegiatan pembinaan hukum nasional. ${ }^{12}$ Sebagai sub sistem pembangunan hukum, dokumentasi hukum ${ }^{13}$ ditugasi untuk menyediakan bahan baku atau data dukung berupa dokumen hukum untuk mendukung semua aktivitas pembangunan hukum. Dalam istilah dokumentasi hukum itu terkandung dua pengertian: 1) dokumentasi hukum dalam pengertian kegiatan yaitu

12 Enny Nurbaningsih, Penataan Regulasi Melalui Analisis dan Evaluasi Hukum dan Peran Jaringan Dokumentasi dan Informasi Hukum Nasional. Disampaikan pada Rapat Koodinasi Penataan Regulasi Diselenggarakan oleh BPHN, Jakarta, 7 Februari 2018, hlm. 18.

13 Dalam istilah dokumentasi hukum tercakup 2 (dua) pengertian, yaitu dokumentasi hukum sebagai lembaga atau unit kerja dan dokumentasi hukum sebagai kegiatan yang dilakukan oleh dokumentasi hukum sebagai lembaga. 
pengumpulan, pemilihan, pengolahan dan menyimpanan informasi dalam bidang pengetahuan ${ }^{14}$ hukum. Secara teknis di lapangan sering disebut pengelolaan dokumen hukum dalam upaya menyediakan akses informasi hukum; 2) dokumentasi hukum dalam pengertian lembaga yang melakukan pengelolaan dokumen hukum. Di instansi pemerintah nomenklatur unit pengelola ini disebut dokumentasi hukum.

Agar dokumentasi hukum mampu melakukan tugasnya menyediakan bahan baku pembangunan dengan cepat, tepat, dan lengkap maka lembaga dokumentasi hukum harus mampu terlebih dahulu menyediakan akses informasi hukum yang efektif. Akses informasi hukum termaksud disediakan melalui pelaksanaan fungsi- fungsi dokumentasi hukum. Apabila dokumentasi hukum tidak mampu menyediakan akses informasi hukum, maka penyediaan dokumen hukum pun akan sulit dilakukan yang berakibat pada terganggunya semua aktivitas pem-bangunan hukum mulai dari perencanaan hukum, penelitian hukum, analisis dan evaluasi hukum, penyusunan naskah akademis, perancangan peraturan dan pembuatan kebijakan oleh para pimpinan.

Dalam era TIK dewasa ini pembangunan hukum nasional khususnya reformasi hukum jilid II, dokumentasi hukum seyogianya memiliki database hukum sebagai media canggih untuk menempatkan konten informasi hukum terintegrasi yang dapat diakses dengan cepat, tepat, dan lengkap melalui internet. Sebagai sub-sistem pembangunan hukum nasional dokumentasi hukum yang ditugasi menyediakan bahan baku harus mampu menyediakan informasi dan dokumen

14 Kamus Besar Bahasa Indonesia, Tim Penyusun Kamus Pusat Bahasa, Jakarta: Balai Pustaka, 2002, hlm. 272. hukum dengan secepat-cepatnya, setepat-tepatnya dan selengkaplengkapnya mendukung aktivitas pembangunan hukum. Database yang dibutuhkan untuk mendukung pembangunan hukum dalam rangka penataan regulasi saat ini adalah Database Hukum Nasional yang berisi informasi hukum terintegrasi.

Uraian di atas menunjukkan betapa strategis dan eratnya hubungan antara dokumentasi hukum dengan pembangunan hukum atau reformasi hukum. Dokumentasi hukum merupakan lembaga penyedia bahan baku pembangunan hukum yang saat ini difokuskan pada penataan regulasi. Untuk memperkuat dukungan dokumentasi hukum terhadap pembangunan hukum tersedianya Data Base Hukum Nasional menjadi sangat penting. Berkenaan dengan hal ini pemanfaatan TIK harus menghasilkan Database berbasis Website dengan informasi hukum terintegrasi. Dengan demikian, selain mampu mempercepat akselerasi pengelolaan dokumen hukum juga mampu mepercepat searching informasi dan retrieval dokumen hukum mendukung pembangunan hukum dan pemenuhan hak asasi publik atas informasi hukum.

\section{Dokumentasi Hukum, Tupoksi dan} Sumber Daya

Dilihat dari cara kerja dan tujuannya, sebenarnya dokumentasi hukum sama dengan perpustakaan khusus, yang secara spesifik mengelola dokumen hukum dengan tujuan khusus yaitu mendukung aktivitas pembangunan hukum. Dalam uraian di atas telah dijelaskan bahwa dalam suatu negara hukum sebenarnya posisi lembaga dokumentasi hukum itu sangat strategis, karena dokumentasi hukum inilah yang bekerja menyediakan akses informasi 
hukum. Di samping penyedia bahan baku bagi semua aktivtas pembangunan hukum, tersedianya akses informasi hukum merupakan salah satu condition sine quanon (syarat yang harus dipenuhi) untuk mewujudkan supremasi hukum. ${ }^{15}$

Akses informasi hukum disediakan melalui pelaksanaan tugas dan fungsi dokumentasi hukum, yang sudah diformat sedemikian rupa dan berlaku secara universal. $^{16}$ Tugasnya adalah menyedia-kan informasi dan dokumen hukum sebagai bahan baku pembangunan. Dalam pelaksanaan tugasnya dokumentasi hukum menyelenggarakan fungsi, antara lain: (1) Pengumpulan dokumen hukum. Fungsi ini dilakukan karena secara alamiah dokumen hukum itu selalu tersebar di berbagai tempat. Untuk keperluan pengolahan harus dikumpulkan terlebih dahulu. (2) Pengolahan Dokumen Hukum. Pengolahan dokumen dilakukan dalam rangka penyediaan akses informasi hukum dalam suatu sistem temu kembali informasi dan dokumen hukum (retrieval information and document law system). Penyediaan akses informasi dilakukan dengan cara mengindentifikasi konten informasi penting dari setiap dokumen dan menuangkannya di atas katalog. Katalog inilah yang berfungsi sebagai alat telusur informasi. (3) Pelayanan Informasi Hukum. Dengan tersedianya "sistem temu kembali informasi dan dokumen hukum" pelayanan informasi dapat dilakukan dengan mudah, cepat dan tepat. (4) Kerja sama (berjaringan). Kerja sama antar dokumentasi hukum dilakukan untuk meningkatkan mutu

15 C.G.F. Sunaryati Hartono, Memberdayakan Pusat Dokumentasi Hukum BPHN sebagai pusat informasi hukum nasional. Majalah Hukum Nasional No. 2 Tahun 2001, Jakarta: BPHN, 2001. hlm. 13-14.

16 Sutarno NS. Manajemen Perpustakaan: suatu pendekatan praktik. Samitra Media Utama: Jakarta, 2004, hlm. 11. pelayanan dengan pendayagunaan bersama informasi dan dokumen hukum (sharing information). Kerja sama dokumentasi hukum disebut JDIHN (Jaringan Dokumentasi dan Informasi Hukum Nasional).

Dalam pelaksanaan tugas pokok dan fungsi dokumentasi hukum yang sering dilupakan adalah penyediaan sumber daya dokumentasi hukum secara memadai. Sumber daya dokumentasi hukum itu terdiri dari: 1) Sumber daya Organisasi; 2) Sumber Daya Manusia; 3) Sumber Daya Koleksi; 4) Sumber Daya Teknis dan Sarana/Prasarana; dan 5) Sumber Daya Dana. ${ }^{17}$

Yang dimaksud dengan organisasi adalah unit kerja atau lembaga dokumentasi hukum. Sebagai sumber daya yang punya daya ungkit, tingkat eselon harus sesuai dengan beban kerja yang ada. Struktur organisasi disusun berdasarkan fungsi dokumentasi dan membagi habis pekerjaan dalam job descriptions, dilengkapi dengan SOP (standar operasi prusedur) untuk setiap kegiatan. Dalam kenyataan di lapangan organisasi dokumentasi hukum ini belum dikembangkan sebagai mana mestinya.

Yang dimaksud dengan Sumber Daya Manusia adalah pimpinan dan staf. Mantapnya organisasi, tidak akan banyak faedahnya tanpa dukungan sumber daya manusia yang memadai dari segi jumlah dan kualitas. Pimpinan seyogianya di samping kompeten di bidang hukum juga harus mengetahui konsep dasar pengelolaan dokumentasi hukum dan bagaimana memanfaatan TIK. Dalam era informasi, fungsional pustakawan dan staf yang terampil melakukan teknis

17 Zulfikar Zen. Peran perpustakaan dalam pembinaan sistem JDI Hukum. Jakarta: Departemen Ilmu Perpustakaan Universitas Indonesia, 2006, hlm. 2. Disampaikan dalam Pertemuan Nasional JDI Hukum, Padang, 24-27 Juli 2006. 
dokumentasi dan mengoperasikan komputer sudah menjadi keharusan. Dalam kenyataannya pimpinan dokumentasi hukum sangat jarang yang memiliki kompetensi dokumentasi hukum demikian juga para staf.

Koleksi merupakan sumber informasi, sedapat mungkin harus selalu lengkap. Semua dokumen hukum hasil kegiatan instansi induk, harus dikumpulkan termasuk dokumen kelabu. Kemudian di tambah dengan dokumen hukum dari luar instansi. Pengadaan sumber informasi hukum ini sering terganggu oleh penyedian dana yang tidak memadai.

Sumber daya teknis berupa modulmodul atau pedoman-pedoman teknis pengelolaan dokumen hukum harus tersedia dengan lengkap. Standardisasi atau pembakuan pedoman teknis memberi bebarapa keuntungan, antara lain: ${ }^{18}$

1. Memberikan keseragaman dan konsistensi dalam pengolahan dokumen hukum (keterpaduan sistem);

2. Memberikan kejelasan tugas bagi unsur-unsur yang terlibat;

3. Mengurangi kesalahan dalam pelaksanaan kegiatan;

4. Menciptakan efisiensi waktu dan biaya.

Sumber Daya Sarana/prasarana adalah segala peralatan dan perlengkapan yang dibutuhkan untuk mendukung pelaksanaan tupoksi dokumentasi hukum. Antara lain: ruangan kerja, ruangan pelayanan dan meja/kursi baca, ruangan dan rak untuk menyimpan koleksi. Fasilitas TIK untuk

18 Lihat Burhanuddin DR, Arti penting pedoman dalam pengelolaaan arsip. Makalah disampaikan pada Apresiasi dalam rangka Penyusunan Pedoman Tata Kearsipan Pemerintah Kabupten Gunung Kidul tanggal 29 Desember 2009 di Wonosari, hlm. 3 mempercepat akselerasi kegiatan dokumentasi hukum berbasis database website harus disediakan secara memadai. Penyediaan sumber daya teknis khususnya dalam era TIK sering terganggu karena pembuatan aplikasi tidak berdasarkan core bisnis dokumentasi hukum.

Sumber daya dana adalah alokasi uang siap pakai yang diperlukan untuk pemeliharaan dan perawatan sistem temu kembali informasi. Misalnya, perbaikan server dan pengadaan sumber informasi tidak mungkin menunggu terlalu lama.

Dalam kenyataannya, tata kelola dokumen hukum masih dipahami banyak pihak sebagai urusan catat mencatat dan menata dokumen, tidak membutuhkan profesionalitas sehingga tupoksi dokumentasi hukum dan penyediaan sumber dayanya sering terlupakan. Pembinaan dan pengembangan tupoksi dan sumber daya dokumentasi ini merupakan tugas dari Pusat JDIHN yang belum dapat diselenggarakan dengan baik.

\section{Jaringan Dokumentasi dan Informasi Hukum Nasional}

Pada hakikatnya JDIHN adalah kerja sama antar unit dokumentasi hukum dalam pengelolaan dokumen hukum agar semua dokumen hukum yang ada dapat didayagunakan bersama. Kemudian secara yuridis dirumuskan dengan "wadah pendayagunaan bersama atas dokumen hukum secara tertib, terpadu, dan berkesinambungan, serta merupakan sarana pemberian pelayanan informasi hukum secara lengkap, akurat, mudah, dan cepat." ${ }^{19}$

\footnotetext{
19 Indonesia. Peraturan Presiden Nomor 33 Tahun 2012 tentang Jaringan Dokumentasi dan Informasi Hukum Nasional (LN Tahun 2012 No. 82) Pasal 1 angka 1.
} 
Istilah "jaringan" dalam frase "JDIHN" tidak sama dengan jaringan internet, seperti yang dipahamkan oleh beberapa orang. JDIHN adalah wadah kerja sama pengelolaan dokumen hukum yang sifatnya nasional. Sementara internet adalah jaringan antar komputer (internetworking of computer networks) dan hanya merupakan jalan tol (superhighway) menuju Website lintas dunia.

Pasal 3 Perpres No. 33/2012 tentang JDIHN menetapkan bahwa tujuan pembentukannya adalah untuk:

a. menjamin terciptanya Pengelolaan Dokumentasi dan Informasi Hukum yang terpadu dan terintegrasi di berbagai instansi pemerintah dan institusi lainnya;

b. menjamin ketersediaan dokumentasi dan informasi hukum yang lengkap dan akurat, serta dapat diakses secara cepat dan mudah;

c. mengembangkan kerja sama yang efektif antara Pusat jaringan dan Anggota jaringan serta antar sesama Anggota jaringan dalam rangka penyediaan dokumentasi dan informasi hukum; dan

d. meningkatkan kualitas pembangunan hukum nasional dan pelayanan kepada publik sebagai salah satu wujud ketata-pemerintahan yang baik, transparan, efektif, efisien, dan bertanggung jawab.

\section{Objek Kerja Sama.JDIHN}

Sebagai wadah kerja sama pendayagunaan dokumen dan informasi hukum, objek yang ditata kelola adalah dokumen dan informasi hukum. Menurut Peraturan Presiden Nomor 33 Tahun 2012 dokumen hukum yang dimaksud meliputi:

"produk hukum berupa peraturan perundang-undangan atau produk selain peraturan perundang- undangan yang meliputi namun tidak terbatas putusan pengadilan, yurisprudensi, monografi hukum, artikel majalah hukum, buku hukum, penelitian hukum, pengkajian ukum, naskah akademik, dan rancangan peraturan perundang-undangan" ${ }^{20}$

Sementara informasi hukum yang dimaksud adalah informasi penting yang terkandung dalam setiap jenis dokumen hukum tersebut di atas. Informasi hukum penting inilah yang dikeluarkan dari setiap dokumen hukumnya pada saat dilakukan pengolahan dokumen hukum.

\section{Bentuk dan Prinsip Kerja Sama}

Bentuk kerja sama JDIHN berupa jaring laba-laba yang terdiri dari Pusat dan Anggota. BPHN (Badan Pembinaan Hukum Nasional Kementerian Hukum dan HAM) ditetapkan sebagai Pusat Jaringan dengan Anggota Jaringan ${ }^{21}$ yang terdiri dari: Biro hukum dan/atau unit kerja yang tugas dan fungsinya menyelenggarakan kegiatan yang berkaitan dengan dokumen hukum. Semua Anggota Jaringan seyogianya mempunyai unit kerja dokumentasi hukum untuk melaksanakan kerja sama pengelolaan dokumen dan informasi hukum. Secara teknis dokumentasi hukum inilah yang melaksanakan kerja sama

JDIHN.
20 Ibid., Pasal 1 angka 3.
21 lbid. 


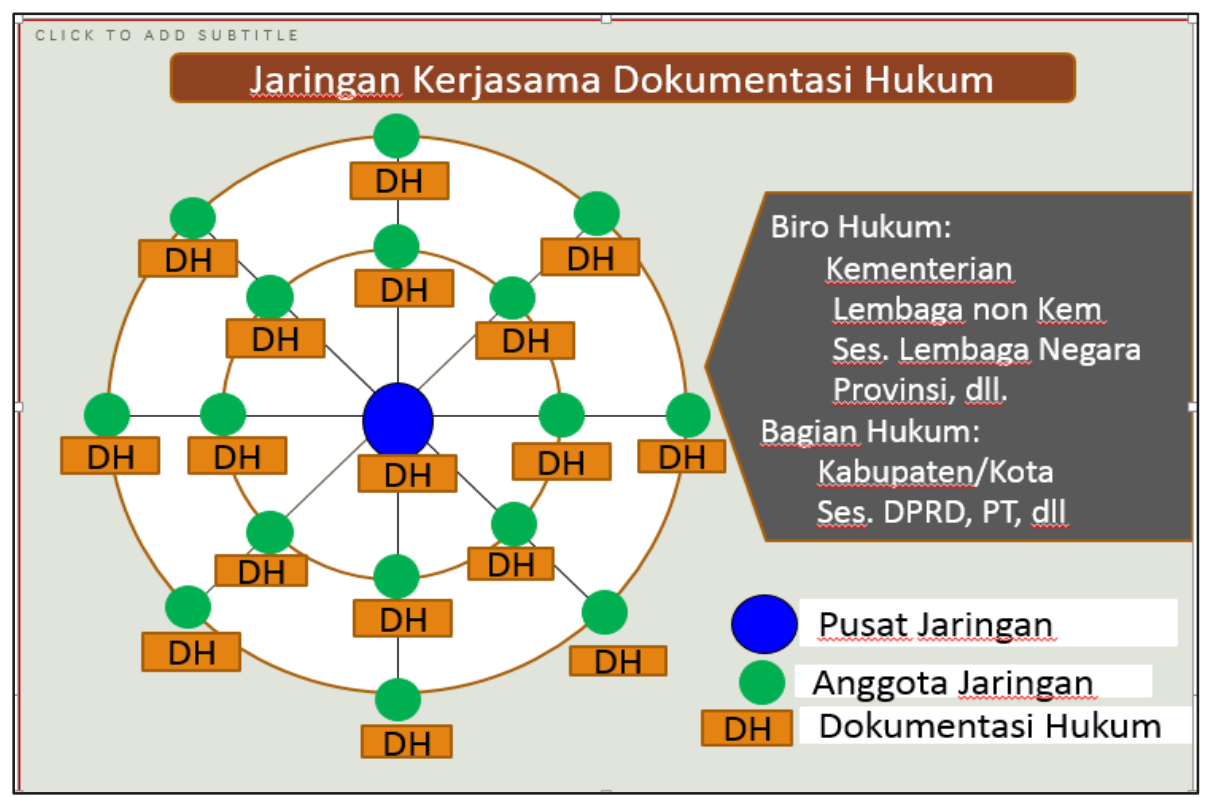

Bentuk Kerja Sama JDIHN

Dalam upaya meningkatkan efisiensi dan efektivitas, kerja sama JDIHN dilaksanakan dengan 3 (tiga) prinsip:

a. Patungan Kerja

Dokumen hukum yang tersebar luas di instansi pemerintah dalam wiayah nusantara adalah milik bangsa Indonesia. Untuk meningkatkan efisiensi dan efektivitas kerja dalam pengelolaan dokumen hukum tersebut. Pengelolaan dokumen dilakukan dengan prinsip "patungan kerja". Yang dimaksud dengan "Patungan Kerja" adalah masing-masing Anggota JDIHN wajib mengumpulkan dan mengelola dokumen hukum yang diproduksi atau dikeluarkan di wilayah kewenangan masing-masing. Misalnya: Biro Hukum Kementerian mengumpulkan dan mengolah dokumen hukum yang dihasilkan/diproduksi di wilayah kementeriannya. Biro Hukum Provinsi mengumpulkan dokumen hukum yang dihasilkan/diproduksi di wilayah Provinsinya. Bagian Hukum Kabupaten/Kota mengumpulkan dokumen hukum yang dihasilkan/ diproduksi di wilayah kewenangannya. Hal yang sama juga berlaku untuk anggota JDIHN yang lain.

Dengan menerapkan prinsip patungan kerja tidak ada lagi duplikasi pekerjaan yang memboroskan uang, waktu dan tenaga yang terjadi selama ini. Duplikasi kerja yang mengakibatkan terjadinya pemborosan terlihat jelas dalam Website Anggota JDIHN dimana hampir semuanya mengelola Undang-Undang, Peraturan Pemerintah, Peraturan Presiden dan yang lainnya.

b. Sharing Information

Dalam upaya meningkatkan pelayanan dan pendayagunaan dari dokumen hukum yang ada prinsip "sharing information" perlu dilakukan. Yang dimaksud dengan sharing information adalah saling berbagi informasi dalam pelayanan informasi hukum. Dalam rangka meningkatkan pendayagunan dokumen dan 
informasi hukum semua Anggota JDIHN wajib melakukan "sharing informastion" atau saling berbagi dokumen dan informasi hukum.

c. Taat SecaraTeknis

Untuk menjamin keseragaman format metadata informasi pengelolaan dokumen menerapkan, prinsip Taat Secara Teknis. Yang dimaksud dengan Taat Secara Teknis adalah pengelolaan dokumen dan informasi hukum wajib menggunakan pedoman/standar teknis pengolahan dokumen dan informasi hukum yang sudah disepakati. Prinsip Taat Secara Teknis merupakan "conditio sine quanon" untuk menciptakan akses informasi hukum yang efektif dan prasyarat untuk penyediaan akses informasi hukum terintegrasi.

Pedoman teknis pengolahan dokumen dan informasi hukum yang digunakan dalam kerja sama JDIHN terdapat di dalam lampiran Peraturan Menteri Hukum dan HAM Nomor 2 Tahun 2013 tentang Standardisasi Pengelolaan Teknis Dokumentasi dan Informasi Hukum.

\section{Informasi Hukum Terintegrasi}

Dalam dunia dokumentasi, pengintegrasian informasi bukan merupakan hal baru. Pengintegrasian informasi sudah dilakukan sejak dokumentasi mengenal kerja sama berjaringan. Pada awalnya informasi hukum terintegrasi dikemas secara hastawi dalam Katalog Induk (Union Catalog). Kemudian di era TIK (Teknologi Informasi dan Komunikasi) informasi hukum terintegrasi dapat dikemas dalam Database Hukum Nasional yang bisa di akses melalui internet.

Dalam katalog induk (Union Catalog) yang dapat diintegrasikan hanya sebatas informasi katalog ${ }^{22}$ yang dikumpulkan dari Anggota Jaringan. Penyusunannya sangat rumit dan membutuhkan waktu yang lama. Pemanfaatannya masih terbatas di perpustakaan, artinya pencari informasi yang mau menggunakannya pun harus berkunjung ke unit Dokumentasi Hukum.

Sementara informasi hukum terintegrasi berbasis Database Website, semua metadata (informasi hukum) dapat diintegrasikan dalam satu database. Selain itu, setiap metadata juga dapat diintegrasikan dengan dokumen hukum yang terkait. Misalnya, mengintegrasikan metadata dengan fullteksnya, risalahnya, abstraknya dan dokumen lain dengan memanfaatkan fasilitas hypertexs-link. Konsep Informasi Hukum Terintegrasi berbasis Database Website mengandung tiga pengertian, yaitu:

1. Informasi katalog (metadata) dari semua dokumen hukum ${ }^{23}$ terintegrasi dalam satu database. Sehingga pencarian informasi cukup dilakukan pada satu database (one stop searching). Misalnya untuk mencari informasi tentang "hukum pajak", cukup dengan mengetikkannya dalam query maka semua informasi mengenai "hukum pajak" dari semua dokumen hukum (peraturan buku, artikel, dll.) dapat ditemukan sekaligus;

2. Semua informasi katalog (metadata) terintegrasi dengan abstrak, anotasi, fullteks, gambar atau audiovisual dalam bentuk doc., pdf., html, dan jpg dengan menggunakan fasilitas hypertexs-link dan dapat di download.

22 Yang dimaksud dengan informasi katalog adalah informasi penting yang diidentifikasi (diambil) dari dokumennya, yang dalam era TIK disebut metadata.

23 Indonesia. Peraturan Presiden Nomor 33 Tahun 2012 Pasal 1 angka 2: 
Misalnya, metadata peraturan diintergrasikan (link) dengan: abstraknya; fullteksnya; risalahnya; peraturan yang mengubahnya, dan/atau peraturan yang mencabutnya.

3. Semua informasi katalog (metadata) yang ada dalam Database Website Anggota JDIHN mudah dipertukarkan (sharing) dengan menggunakan protokol komunikasi OAI-PMH (Open Access Information - Protokol Metadata Harvester). ${ }^{24}$ Dengan demikian semua informasi hukum yang ada terintegrasi dalam Website Anggota JDIHN dapat diakses atau ditelusur melalui Portal JDIHN. Artinya semua metadata dan dokumen hukum terkait yang ada dalam database Anggota JDIHN dapat di download dan dijadikan Database Hukum Nasional.

\section{Pemanfatan TIK Membentuk Database Hukum Nasional}

Untuk mewujudkan informasi hukum terintegrasi, pemanfaatan TIK merupakan suatu keharusan. Untuk memahami pemanfaatannya bagi kerja sama JDIHN perlu diketahui bahwa menurut Putu Laaxman Pendit:

"TIK merupakan kolaborasi dari 3C (Computer, Communication, Content). Dalam hal ini internet hanya terfokus pada jaringan fisik yaitu Computer (komputer) dan Communication (telekomunikasi), sementara Content (informasi) diletakkan dalam jaringan fisik tersebut agar bisa diakses melalui internet". ${ }^{25}$

24 Ari Nugraha. Interoperabilitas Metadata Dalam membangun kerja sama JDIHN baik di Pusat maupun di Daerah. Paper Disiapkan Anggota Tim Pembina dan Pengembangan JDIHN Untuk Badan Pembinaan Hukum Nasional Tahun 2016 hlm. 6

25 Putu Laxman Pendit, Teknologi informasi untuk Jaringan Dokumentasi dn Informasi Hukum: aspek organisasi dan SDM. Makalah lepas, hlm. 1.
Sementara untuk Content istilah yang digunakan adalah WWW atau Website, yakni berupa sebuah sistem komputer yang berindak sebagai server bagi sistem informasi dan dilengkapi dengan sistem database pengelolaan data. $^{26}$ Database pengelola data inilah yang disebut Database Website dengan Content informasi. Dalam kerja sama JDIHN database inilah yang disebut Database Hukum Nasional dengan konten informasi hukum terintegrasi.

Apabila seseorang berselancar melalui internet, pasti akan menemukan banyak instansi telah siap dengan internet untuk menyebarkan informasi, tetapi penyediaan content belum ditangani dengan baik. Akibatnya, tersedianya internet tidak begitu banyak faedahnya. Penyediaan Content ini harus dilakukan secara profesional, agar informasi dalam beragam bentuk dan isi menjadi suatu informasi yang dapat digunakan oleh pencari informasi secara mudah, tepat, cepat. ${ }^{27}$

Dalam tata kelola dokumentasi hukum konten (isi) database seharusnya informasi hukum terintegrasi agar efektif digunakan dalam pencarian informasi (searching information) dan temu kembali dokumen (retrieval documentation). Dalam kerja sama JDIHN, penyediaan Content (informasi hukum terintegrasi) inilah yang menjadi tanggung jawab utama dari Pusat dan Anggota JDIHN.

Namun perlu diperhatikan bahwa dalam pengelolahaan dokumen dan informasi hukum, TIK hanya suatu alat. Alat canggih yang mampu mempercepat

26 Andrari Grahitandaru. Teknologi informasi dan komunikasi untuk meningkatkan kreativitas dan Kesadaran Hukum. Makalah lepas. 2009, hlm. 4.

27 B. Mustofa. Intenet dan layanan informasi hukum. Makalah disampaikan dalam Pelatihan staf Perpustakaan dan Dokumentasi BPHN, tanggal 67 Oktober 1998, hlm. 1. 
segala macam proses. Termasuk mempercepat proses pengelolaan dokumen hukum dan mempercepat penyebarluasan informasi hukum melalui internet. Sebagai alat canggih, pemanfaatan TIK harus disesuaikan dengan kebutuhan penggunanya. Jika penggunanya pengelola dokumen dan informasi hukum, maka TIK dimanfaakan untuk membentuk Database Hukum Nasional yang diperlukan oleh pengelola dokumen untuk mempercepat akselerasi pengolahan dan penyebarluasan informasi hukum. Artinya pengelolaan dokumen membutuhkan satu media canggih berupa Database Hukum Nasional yang dirancang secara khusus untuk mempercepat proses bisnis dokumentasi hukum dan sekaligus mengintegrasikan semua informasi hukum.

Perlu juga diketahui bahwa pembangunan hukum nasional tidak hanya membutuhkan dokumen hukum berupa peraturan-perundang-undangan saja. Pembangunan hukum membutuhkan semua jenis dokumen hukum sebagai bahan baku. Oleh karena itu Database Hukum Nasional tidak hanya berisi informasi peraturan perundangundangan tetapi juga berisi informasi hukum non peraturan perundangundangan. Agenda pembentukan database peraturan perundang-undangan sebaiknya dimaknai pembentukan Database Hukum Nasional. Karena dalam persepsi banyak orang di luar kalangan hukum, hukum adalah sama dengan peraturan perundang-undangan atau sebaliknya peraturan perundangundangan adalah hukum.

Perkembangan TIK sudah sedemikian jauh, telah mampu menyediakan database yang mampu mengklaster (mapping) tipe dan sub-tipe dari semua jenis dokumen dan sekaligus menunjukkan berapa jumlahnya. Sehingga jika ada yang bertanya mana database peraturan perundang-undangan atau mana database hasil penelitian atau mana database artikel hukum dan dokumen hukum yang lain bisa langsung menunjuk ke mapping database. Bahkan TIK sudah menyediakan fasilitas untuk mengambil semua metadata dan dokumen hukum yang ada dalam database, dan disatukan menjadi Database Hukum Nasional.

Untuk mendorong sekaligus memudahkan Anggota JDIHN melakukan tugasnya menyediakan akses informasi hukum terintegrasi, Pusat JDIHN sudah mengembangkan Aplikasi Pengelolaan Dokumen dan Informasi Hukum yang disebut Aplikasi Website JDIHN dan di launching di Jakarta, tanggal 29 Agustus 2016. Uji coba telah dilakukan di Kantor Wilayah Kementerian Hukum dan HAM. Hasilnya kinerja pengelolaan dokumen hukum menunjukkan kenaikan dan pengintegrasian informasi hukum berhasil dengan baik.

Anggota JDIHN yang belum mempunyai database untuk pengelolaan dokumen hukum, dapat mengunduh (download) Aplikasi Website JDIHN dari Website BPHN dan menggunakannya. Apabila ada kendala dalam penggunaannya dapat menghubungi Pusat JDIHN untuk mendapat bimbingan langsung melalui telepon dan alat komunikasi lainnya. Bagi Anggota JDIHN yang sudah punya database untuk pengolahan dokumen hukum dianjurkan untuk menyesuaikan dengan Aplikasi Website JDIHN. Penyesuaian cukup dilakukan dengan memenuhi standar metadata minimal di bawah ini:

\begin{tabular}{|c|c|}
\hline UNSUR SEMANTIK & DOKUMEN HUKUM \\
\hline Type/Sub type Dokumen & Peraturan, Monografi hukum, Artikel hukum \\
\hline
\end{tabular}




\begin{tabular}{|l|l|}
\hline \multicolumn{1}{|c|}{ UNSUR SEMANTIK } & \multicolumn{1}{c|}{ DOKUMEN HUKUM } \\
\hline Judul & Peraturan, Monografi hukum, Artikel hukum \\
\hline Pencipta (Creator) & Peraturan, Monografi hukum, Artikel hukum \\
\hline Subjek & Peraturan, Monografi hukum, Artikel hukum \\
\hline Bentuk Peraturan & Peraturan \\
\hline Singkatan Bentuk & Peraturan \\
\hline Nomor Peraturan & Peraturan \\
\hline Status & Peraturan \\
\hline Tahun & Peraturan, Monografi hukum, Artikel hukum \\
\hline Lampiran berkas & Fulteks, Abstrak, Gambar, dll \\
\hline Bahasa & Peraturan, Monografi hukum, Artikel hukum \\
\hline Sumber & Peraturan, Artikel \\
\hline
\end{tabular}

Hal ini perlu dlakukan untuk mempercepat pengolahan dokumen yang selama ini terbengkalai sekaligus memperkuat dukungan terhadap pembangunan hukum khususnya program prioritas Reformasi Hukum Jilid II, yaitu penataan regulasi. Penataan regulasi membutuhkan akses informasi hukum terintegrasi berbasis database yang dapat diakses melalui internet.

Satu hal yang sangat penting dalam Aplikasi Website JDIHN berkenaan dengan Integrasi Informasi Hukum secara nasional adalah interopabilitas informasi dengan menggunakan OAI-PMH (Open Archives Initiative for Metadata Harvesting). sehingga pertukaran informasi dapat dilaksanakan secara real time. OAI-PMH adalah sebuah protokol dengan konsep client-server yang sangat penting untuk keseragaman dalam melakukan sharing metadata. Sementara untuk memudahkan pemasangan (isntall) telah disediakan paket senayan yang berisi program Senayan, apache, PHP, dan, MySQL. Pengguna tinggal mengopi, mengekstrak dan langsung menggunakan-nya pada komputer atau server masing-masing.
Untuk menginstal Aplikasi Pengelolaan Website JDIHN, perlu disediakan computer personal (Personal Computer/PC), laptop atau yang sejenisnya dengan spesifikasi minimum sebagai berkut:

1. Perangkat keras yang dibutuhkan:
a. Prosessor kelas Pentium III
b. RAM 256MB
c. Standard VGA dengan dukungan warna 16-Bit
d. Harddisk $\pm 1 \mathrm{~GB}$
e. CDROM / DVDROM
f. Keyboard dan Mouse

2. Perangkat lunak yang akan dibutuhkan: a. Engine scripting PHP dengan
dukungan ekstension mysql, dukungan XML dan GD untuk dapat mendukung format file .PNG, .JPG, GIF dan Freetype;

b. Web Server, dalam hal ini direkomendasikan Apache 2.2;

c. Server Database MySQL dan direkomendasikan lebih atau sama dengan versi 5.0;

d. Utility mysqldump untuk backup database; 
e. Sistem Operasi GNU/Linux atau Windows;

f. Browser dengan kapasita javascript 1.5 AJAX dan CSS 2, sebagai contoh Mozilla Firefox 2;

g. Pembaca dokumen PDF seperti Adobe Reader untuk melihat dokumen PDF yang di generate.

3. Kelebihan yang dimiliki oleh Aplikasi Website JDIHN antara lain:

a. Dapat diperoleh dan digunakan secara gratis;

b. Mampu memenuhi kebutuhan otomasi pengelolaan dokumen dan informasi hukum;

c. Aplikasi dibangun dengan menggunakan bahasa pemograman interpreter yang memungkinkan untuk dimodifikasi;

d. Instalasi mudah dilakukan;

e. Memiliki prospek pengembangan yang jelas;

f. Memiliki forum komunikasi antara pengguna dan pengembangan.

\section{Penutup}

Dari uraian di atas dapat diketahui bahwa penyediaan Database Hukum Nasional untuk mendukung pembangunan hukum nasional membutuhkan peranan JDIHN sangat strategis. Namun pengetahuan mengenai konsep-konsep pengelolaan dokumen hukum, kemampuan teknisnya pengelolaan dokumen hukum dan pengetahuan tentang pemanfaatan TIK masih belum memadai. Untuk mempercepat penyediaan Database Hukum Nasional, peran Pusat dan Anggota JDIHN perlu ditingkatkan dengan mengetahui dan memahami beberapa hal di bawah ini:

Dokumentasi hukum dan pembangunan hukum mempunyai hubungan yang sangat erat, karena dalam sistem pembangunan hukum nasional, dokumentasi hukum merupakan salah satu sub-sistem yang tugasnya menyediakan bahan baku berupa dokumen hukum untuk menunjang semua kegiatan pembangunan hukum.

Dokumentasi hukum merupakan salah satu jenis perpustakaan yang secara khusus mengelola dokumen hukum dengan tujuan khusus yaitu mendukung pembangunan hukum nasional. Tugasnya melakukan pengelolaan dokumen hukum Dalam rangka menyediakan akses informasi hukum terintegrasi dalam satu database. Dalam melaksanakan tugasnya membutuhkan sumber daya: organisasi, manusia, dokumen hokum, teknis, sarana/prasarana dan dana.

JDIHN dibentuk karena dokumentasi hukum belum mampu melaksanan tugasnya dengan baik, karena menghadapi berbagai faktor penghambat yang kompleks. Melalui pembentukan JDIHN diharapkan kerja sama antara Pusat dan Anggotanya dapat mengatasi berbagai masalah pengelolaan dokumen hukum sehingga mampu menyediakan akses informasi hukum yang efektif mendukung pembangunan hukum yang difokuskan pada penataan regulasi.

Objek kerja sama JDIHN adalah pengelolaan dari dokumen hukum yang tersebar di seluruh wilayah nusantara. Semua dokumen hukum tersebut harus ditata kelola dengan baik agar dapat didayagunakan secara bersama-sama.

Untuk meningkatkan efisiensi dan efektivitas kerja, pengumpulan dan pengolahan dokumen hukum dilakukan dengan "patungan kerja". Sementara untuk meningkatkan layanan informasi hukum dan pendayagunaan dari dokumen hukum yang ada, semua Anggota JDIHN melakukan sharing information atau saling berbagi informasi. Menyediakan Informasi hukum terintegrasi merupakan salah satu tujuan dari pembentukan JDIHN. Dalam konsep informasi hukum terkandung tiga 
pengertian, pertama: semua metadata informasi hukum terintegrasi dalam satu database; kedua: setiap metadata terintegrasi dengan dokumen hukum terkait; ketiga: semua informasi dan dokumen hukum yang ada dalam database Anggota JDIHN terintegrasi dalam suatu sistem dan dapat diakses melalui satu portal. Artinya semua metadata dan dokumen hukum terkait bisa diambil dan disatukan dalam satu database nasional (Database Hukum Nasional).

Untuk mewujudkan informasi hukum terintegrasi, pemanfaatan TIK merupakan suatu keharusan untuk membentuk media canggih berupa database yang dirancang secara khusus untuk mempercepat proses bisnis dokumentasi, dan content informasi hukum terintegrasi untuk mempercepat pencarian informasi hukum dan temu kembali dokumen hukum.

Untuk meningkatkan peran JDIHN dalam mempercepat penyediaan Database Hukum Nasional, disarankan agar semua pokok-pokok pikiran di atas disosialisasikan kepada semua Anggota JDIHN melalui berbagai kegiatan yang dilakukan dalam pembinaan dan pengembangan JDIHN. 


\section{DAFTAR PUSTAKA}

\section{A. Buku}

Notopuro, Harjito, Tugas dan Peranan Pusat Dokumentasi Hukum Badan Pembinaan Hukum Nasional dalam rangka pengembangan sistem jaringan dokumentasi dan informasi hukum (Jakarta: BPHN, 1980).

NS, Sutarno, Manajemen Perpustakaan: suatu pendekatan praktik (Jakarta: Samitra Media Utama, 2004).

\section{B. Makalah/Artikel/Prosiding/Hasil Penelitian}

Budiarto, M (Ses. BPHN). Peranan Dokumentasi dan Informasi Hukum Dlam Rangka Menunjang Para Pejabat Pengambil Keputusan. Makalah disampaikan dalam Pengarahan Pada Latihan Tenaga Teknis Dokumentasi ddan Informasi Hukum Tingkat Dasar Departemen Kehakiman , 11 Peburari 1991 s.d. 12 Maret 1991 di Jakarta.

DR, Burhanuddin, Arti penting pedoman dalam pengelolaaan arsip. Makalah disampaikan pada Apresiasi dalam rangka Penyusunan Pedoman Tata Kearsipan Pemerintah Kabupten Gunung Kidul tanggal 29 Desember 2009 di Wonosari.

Grahitandaru, Andrari, Teknologi informasi dan komunikasi untuk meningkatkan kreativitas dan Kesadaran Hukum. Makalah lepas. 2009.

Hartono, C.G.F. Sunaryati, Memberdayakan Pusat Dokumentasi Hukum BPHN sebagai pusat informasi hukum nasional. Majalah Hukum Nasional No. 2 Tahun 2001 (Jakarta: BPHN, 2001).

Himpunan Hasil Seminar Hukum Nasional I-VII dan Seminar Akbar 50 Tahun Pembinaan Hukum (Jakarta: PNRI, 2003).

Kamus Besar Bahasa Indonesia, Tim Penyusun Kamus Pusat Bahasa (Jakarta: Balai Pustaka, 2002).

Menteri Hukum dan Ham RI, Keynote Speech disampaikan dalam Rapat Koordinasi Penataan Regulasi diselenggarakan oleh BPHN. Jakarta, 7 Pebruari 2018.

Mustofa, B, Intenet dan layanan informasi hukum. Makalah disampaikan dalam Pelatihan staf Perpustakaan dan Dokumentasi BPHN, tanggal 6-7 Oktober 1998.

Nugraha, Ari, Interoperabilitas Metadata Dalam membangun kerja sama JDIHN baik di Pusat maupun di Daerah. Paper Disiapkan Anggota Tim Pembina dan Pengembangan JDIHN Untuk Badan Pembinaan Hukum Nasional Tahun 2016. 
Nurbaningsih, Enny, Penataan Regulasi Melalui Analisis dan Evaluasi Hukum dan Peran Jaringan Dokumentasi dan Informasi Hukum Nasional. Disampaikan pada Rapat Koodinasi Penataan Regulasi Diselenggarakan oleh BPHN, Jakarta, 7 Februari 2018.

Pendit, Putu Laxman, Teknologi informasi untuk Jaringan Dokumentasi dn Informasi Hukum: aspek organisasi dan SDM. Makalah lepas.

Setiadi, Wicipto, kebijakan badan pembinaan hukum nasional dalam pembinaan dan pengembangan Jaringan Dokumentasi dan Informasi Hukum Nasional. Makalah disampaikan dalam Pertemuan Berkala Ke XX Anggota JDI-Hukum Nasional Wilayah Barat tanggal 24 s.d. 26 Mei 2011 di Palembang.

Zen, Zulfikar, Peran perpustakaan dalam pembinaan sistem JDI Hukum. Jakarta: Departemen IImu Perpustakaan Universitas Indonesia, 2006. Disampaikan dalam Pertemuan Nasional JDI Hukum, Padang, 24-27 Juli 2006.

\section{Peraturan Perundang-undangan}

Peraturan Presiden Nomor 33 Tahun 2012 tentang Jaringan Dokumentasi dan Informasi Hukum Nasional (LN Tahun 2012 No. 82) Pasal 1 angka 1.

Instruksi Presiden Nomor 9 Tahun 2011 tentang Rencana Aksi Pencegahan dan Pemerantasan Korupsi Tahun 2011. Lampiran point 72. 